\title{
SPALVA NAUJOJOJE VILNIAUS ARCHITEKTŪROJE
}

\author{
Romualdas Kučinskas \\ Architektūros katedra, Vilniaus dailès akademija, \\ Maironio g. 6, LT-01124 Vilnius, Lietuva \\ El.paštas rkucinskas@yahoo.com
}

Iteikta 20090512

\begin{abstract}
Santrauka. Šio tyrimo tikslas yra atkreipti dèmesị $\mathfrak{i}$ Lietuvoje mažai tyrinėtą temą. Taip pat apžvelgti jau atliktus spalvos tyrimus ir atsirinkti architektūrinei kompozicijai tinkamus tyrinèjimo metodus. Remiantis šiais metodais, nagrinëjami XXI a. pradžios Vilniaus architektūros spalviniai sprendimai. Nagrinejjant stengiamasi apsiriboti formaliomis, tai yra išorinėmis vizualinėmis kompozicijos savybėmis.

Apžvelgiant spalvos naudojimą Vilniaus architektūroje, pasinaudota I. Araucho pasiūlyta metodine schema. Nagrinëjant spalvos ir architektūros santykị, jis siūlo pasitelkti glaudžiai tarpusavyje susijusius komponentus - tūrị ir paviršių, spalvą ir šviesą. Araucho schemoje šviesa nèra vien tik fizinis ar metafizinis faktorius, ji yra lygiavertis spalvai kompozicijos dèmuo. Tai leidžia ịtraukti $\underset{t}{ }$ spalvinès kompozicijos tyrimus reikšmingus achromatinès modernios architektūros pastatus.

Apžvelgus spalvos naudojimą šiandieninejje Vilniaus architektūroje reikia konstatuoti, kad mieste neveikia holistiniu, visuotiniu principu funkcionuojantys spalviniai savitumai. Mieste vienu metu yra taikomos skirtingos spalvinès koncepcijos. Viena iš jų tęsia modernistinę, achromatinès architektūros kryptị. Kita koncepcija bando pratęsti spalvos naudojimo tradicijas architektūroje. Nagrinejjant atskirų pastatų spalvines kompozicijas, pastebimas siekis atskirti spalvą nuo kompozicijos tektonikos. Pastatai kuriami kaip vizualiai netektoniški objektai. Vietoj tūrio kuriamas reginys.
\end{abstract}

Reikšminiai žodžiai: tūris, paviršius, šviesa, spalva, kompozicija, spalvinẻ koncepcija.

\section{Ivadas}

Šio tyrimo tikslas yra atkreipti dèmesị i Lietuvoje mažai tyrinètą temą. Taip pat apžvelgti jau atliktus spalvos tyrimus ir atsirinkti architektūrinei kompozicijai tinkamus tyrinejjimo metodus. Remiantis šiais metodais, nagrinèjami XXI a. pradžios Vilniaus architektūros spalviniai sprendimai. Nagrinejjant stengiamasi apsiriboti formaliomis, tai yra išorinėmis vizualinemis kompozicijos savybèmis.

\section{Spalvų naudojimo kontekstas}

Šiandieninę spalvos naudojimo praktiką nulèmé daugelis priežasčiu, tarp kurių reikia paminèti modernios XX a. architektūros santykị su spalva. Tai labai plati tema, kuriai gali būti skirtas atskiras straipsnis. Tačiau tai peržengtų užsibrèžtas tyrimo ribas, todèl verta glaustai pažymėti tik keletą priežasčių.
Prie modernios architektūros ištaku stovejo tokie koloristikos grandai kaip Johanes Itten (Иттен 2004), Teo von Doesburg, Piet Mondrian (Warncke 1990), spalvinius pastatų projektus kūrè Le Corbusier. Spalva architektūroje naudota pakankamai plačiai. Tačiau tolesnè stilistinè modernios architektūros raida, industrinè statybos praktika ir jai būdingos statybinès medžiagos (modernistinè „trejybë“ - stiklas, plienas, betonas) nulèmé, kad spalva buvo nustumta ị architektūrinès praktikos pakraščius.

Technologiniai faktoriai lėmé, kad XX a. antros pusès spalviniai sprendimai Lietuvoje apsiribojo natūralių konstruktyvinių ir apdailos medžiagų spalvos naudojimu: geltono ar raudono molio plytos, granitinis ar kalkinis žèručio tinkas ir pan. Architektūrinè kūryba vyko esant būdingam tam laikotarpiui išraiškos priemonių trūkumui. Dažymo, spalvos naudojimo 
igūdžiai naujoje architektūroje palaipsniui menko, o spalva dažniausiai buvo naudojama tik detalèms ir atskiriems tektoniniams elementams spalvinti.

Būta ir keletas bandymų sugrąžinti spalvą i̇ architektūrą. Pirmasis jų sutapo su aštuntąjj dešimtmeti Lietuvą pasiekusiomis postmodernistinès architektūros idèjomis. Tačiau šis laikotarpis tęsèsi gana trumpai. Buvo pastatyti vos keli pastatai. Tarp jų bankas „Hermis“ (archit. K. Pempe ir kt.) bei „Prekybos centras 2000“ Vilniuje, Jogailos g. (archit. A. Songaila ir kt.). Be to, dalis lietuviškos postmodernios architektūros buvo sukurta taikant achromatinę, nespalvotą spalvinę skalę. Charakteringi pavyzdžiai Vilniuje - daugiabutis gyvenamasis namas Šv. Mikalojaus g. bei administracinis pastatas Ašmenos g. (archit. A. Trimonis ir kt.).

Antrasis spalvos sugrịžimo etapas sutapo su Nepriklausomybès atkūrimu. Atsiradęs naujų statybinių medžiagų ir technologijų importas pasiūlè iki tol neregètas spalvines galimybes. Tačiau pirmųjų bandymų rezultatai nebuvo džiuginantys. Nepamatuotos užsakovų ambicijos, neišprusimas ir ịgūdžių nebuvimas tarp architektų lèmė groteskiškus, neharmoningus, kakofoniškus spalvinius bei medžiaginius sprendimus. Šių sprendimų pasekmès matomos iki šiol.

Kita priežastis, lèmusi antraeilị spalvos vaidmeni šiandieninèje architektūroje, yra kultūrinio pobūdžio. Spalva, kadaise buvusi visuotino, holistinio pasaulio suvokimo dalis, turèjo neatsiejamą fizinę ir prasminę išraišką. Tai yra spalva buvo ne tik fizinè daikto savybè, bet ir simbolis. Vientisas spalvinių simbolių naudojimas buvo ir vientiso spalvinių kodų supratimo ir naudojimo pagrindas. Tai užtikrino prasminị ir estetinị vientisumą. Šiuo metu toks vientisumas palaipsniui yra. Papildomą sumaištį kelia ir laisvai skolinami spalviniai deriniai iš kitų kraštų ir kultūrų.

Šiandien spalva praranda savo simbolinę prasmę ir daugiausia yra suvokiama bei naudojama utilitariai. Vyraujančiu tampa taikomasis spalvos pobūdis, kai spalva naudojama slopinti ar aktyvinti, siekiant padidinti ar sumažinti (Jonaitis 2008), užmaskuoti ar, atvirkščiai, paženklinti ir atkreipti dèmeși (Mogilnickas 1995).

\section{Spalvų nagrinèjimo metodas}

Spalvos tyrimai yra išsišakoję daugeliu krypčių: nuo spalvos prigimties ar spalvos prasmės nagrinèjimo iki spalvos poveikio žmogui tyrimų; nuo fizikos ir koloristikos iki semantikos ir psichologijos. Tarp garsiausių mokslininkų ir menininkų, tyrusių spalvą, būti- na paminèti Isaac Newton ir Johann Goethe, Vasilyj Kandinsky, Johhanes Itten, Mariją Gimbutienę, Rudolf Arnheim ir Sven Hesselgren. Spalvai architektūrinèje kompozicijoje didelị dèmesị skyrè Ignacio Araujo. Kadangi pagrindiniu mano tyrimo aspektu yra spalva architektūroje, apžvelgdamas Vilniaus pastatus pasinaudosiu būtent šio teoretiko pasiūlyta metodine schema (Apayxo 1982).

Nagrinejjant spalvos ir architektūros santykị, jis siūlo pasitelkti glaudžiai tarpusavyje susijusius komponentus - tūrị ir paviršių, spalvą ir šviesą. Araujo siūlomas metodas yra nepalyginamai produktyvesnis nei kiti, paprastai atskiriantys šviesos ir spalvos problematiką (Samalavičius 2004). Araujo schemoje šviesa nèra metafizinis ar tik fizinis faktorius, paaiškinantis šviesos bangų koncepciją, spalvų matymo mechanizmą bei spalvų spektro kilmę. Šviesa yra lygiavertis spalvai kompozicijos dèmuo. Tai leidžia plačiau pažvelgti i spalvos problemą, įtraukti $\mathfrak{i}$ spalvinès kompozicijos tyrimus reikšmingus achromatinès modernios architektūros pastatus.

Pasinaudojus keturiais išvardintais komponentais, pateikta keletas spalvos naudojimo schemų:

- Tūris ir spalva. Tai schema, kurioje vientisas tūris yra dažomas ar kitaip dengiamas viena spalva arba harmoningu spalvų deriniu.

- Tūris ir šviesa. Tai schema, kurioje architektūrinis tūris yra modeliuojamas taip, kad jo pobūdis išryšketų krintant šviesai. Šiuose pastatuose naudojami achromatiniai tonai (balta, pilka, juoda) arba nedidelio intensyvumo spalviniai deriniai, sukuriantys bendrą pilkumo įspūdị.

- Paviršius ir spalva. Ši schema naudojama architektūroje, pasižyminčioje sudètingomis formomis ar paviršiaus modeliavimu. Didelis dèmesys tokioje architektūroje teikiamas faktūrai, tekstūrai ir jų spalviniam sprendimui.

- Paviršius ir šviesa. Tai schema, artima prieš tai ịvardintai trečiai schemai, tačiau spalvinius derinius čia keičia achromatiniai deriniai ir šviesotamsos sprendiniai.

Remiantis išvardintomis spalvinemis schemomis bus nagrinejjami kompoziciniai uždaviniai, iškylantys atskiruose architektūriniuose objektuose. Tai yra tyrinejjamos naudojant spalvą keičiamos formalios, vizualinès fizinès atskiro pastato ar jo dalių savybès. Stebima, ar pastatas didinamas arba mažinamas, skaidomas ar jungiamas. Taip pat tyrime spalva nagrinejjama ir didesnio mastelio architektūrinèse kompozicijose, ap- 
žvelgiant pastatų grupę, kompleksą ar net mikrorajoną. Žiūrima, ar naudojant spalvą pastatas derinamas prie aplinkos, konteksto arba išskiriamas iš jo.

\section{Spalvinių sprendimų pavyzdžiai}

Neskirstydamas pastatų pagal tipologinius, stilistinius ar kitus požymius pabandysiu apžvelgti spalvinių schemų naudojimą konkrečiais pavyzdžiais. Naujausioje Vilniaus architektūroje galima rasti visas keturias spalvines schemas.

1 schema - tūris ir spalva. Pavyzdžiai: LNK studijos pastatas Šeškinès mikrorajone („Paleko ARCH studija“, 1 pav.), administracinis pastatas Šeškinès mikrorajone (UAB „Vilniaus architektūros studija“, 2 pav.), „Senukų“ prekybos centras Ukmergès g. (archit. A. Žalys, 3 pav.), viešbutis „Europa City“ (UAB „Forma“, 4 pav.).

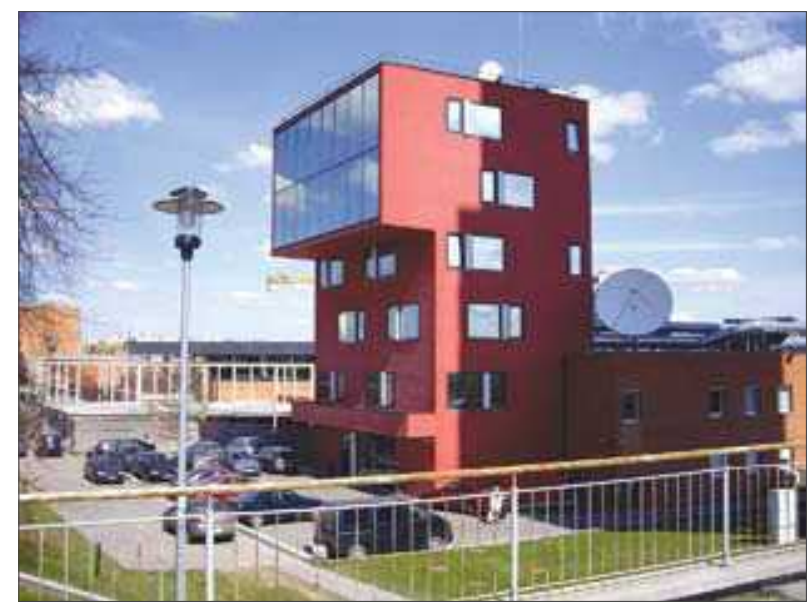

1 pav. LNK televizijos studija

Fig. 1. LNK television studio

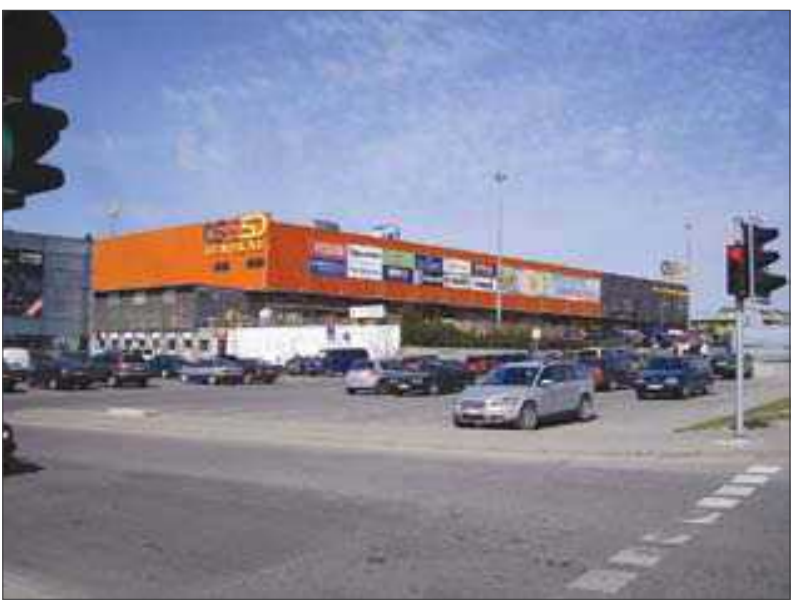

3 pav. "Senukü" prekybos centras

Fig. 3. Shopping center "Senukai"
2 schema - tūris ir šviesa. Pavyzdžiai: Nacionalinis muziejus Konstitucijos pr. (pastato autorius archit. G. Baravykas, rekonstrukcijos archit. A. Bučas ir kt., 5 pav.), Generalinès prokuratūros pastatas (archit. K. Lupeikis, 6 pav.), gyvenamieji namai Baltupių mikrorajone (UAB „AKG“, 7 pav.), administracinis pastatas Žirmūnų g. (UAB „AKG“, 8 pav.).

Galima įžvelgti keletą spalvinių išvardytų objektų santykio su aplinka koncepcijų. LNK studija ir administracinis pastatas Šeškinès mikrorajone tęsia tarybiniais metais suformuotą spalvini Šeškinès mikrorajono kodą - pilki betoniniai gyvenamieji pastatai ir raudonas mūrinis daugiafunkcis mikrorajono centras.

Naujiems gyvenamiesiems namams Baltupių mikrorajone būdinga priešinga kryptis. Šie pastatai netęsia mikrorajono spalvinio kodo - pilkos betono

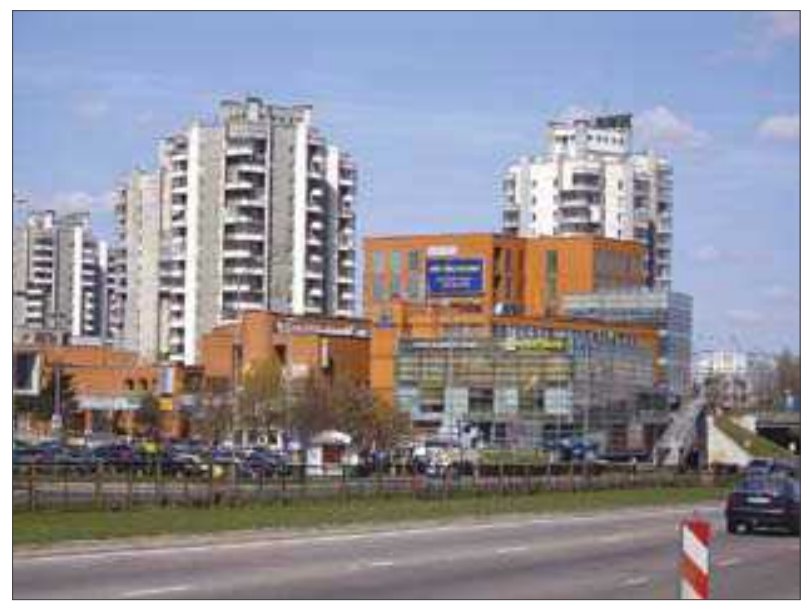

2 pav. Administracinis pastatas Šeškinès g.

Fig. 2. Administration building in Šeškinè str

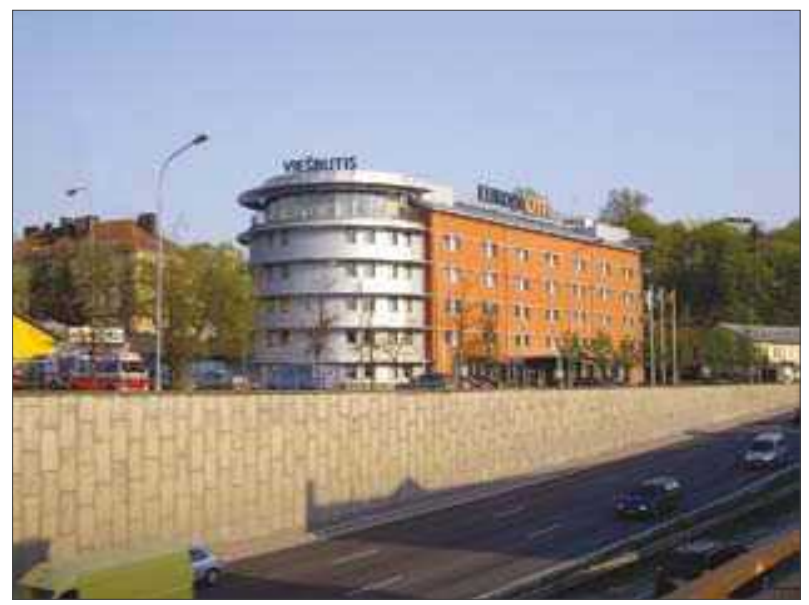

4 pav. Viešbutis "Europa City"

Fig. 4. Hotel "Europa City" 


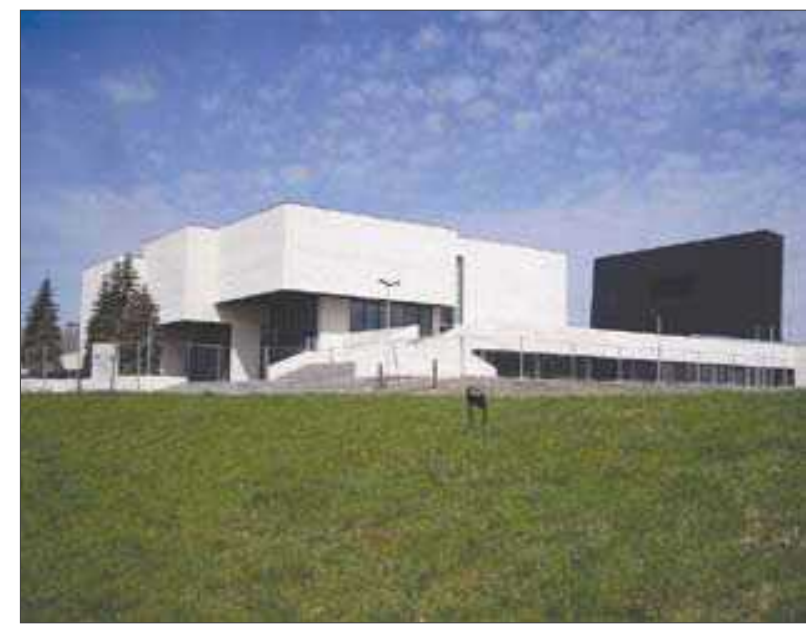

5 pav. Nacionalinis muziejus

Fig. 5. National Museum

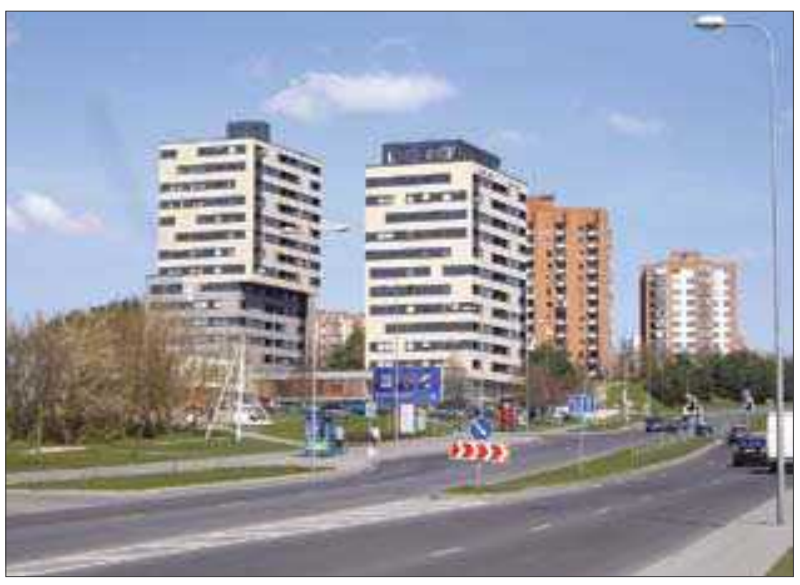

7 pav. Gyvenamieji namai Baltupių mikrorajone

Fig. 7. Residential houses in Baltupiai district

horizontalès ir raudonos mūro vertikalès. Naujuose vertikalaus pobūdžio statiniuose naudojamos kitos fasado apdailos medžiagos ir achromatiniams tonams artimos spalvos.

Kitą spalvinę koncepciją galima įžvelgti pastatuose, kurie spalvinami reaguojant ne į aplinkos užstatymą, o i judejiimą, aktyvumą ir transportą. Intensyvi šių pastatų spalva skirta paženklinti juose vykstančiai aktyviai veiklai, atkreipti transportu keliaujančių žmonių dèmesiui, tapti orientyru, judant urbanistinèje aplinkoje. Šiai koncepcijai tiktų „Senukų“ prekybos centro, viešbučio „Europa City“, iš dalies ir LNK studijos pavyzdžiai. Kalbant apie spalvos naudojimo kokybę, pastato santykị su aplinka, „Senukų“ centrą reiktų laikyti neharmoningu pavyzdžiu. Stambus vientisas tūris,

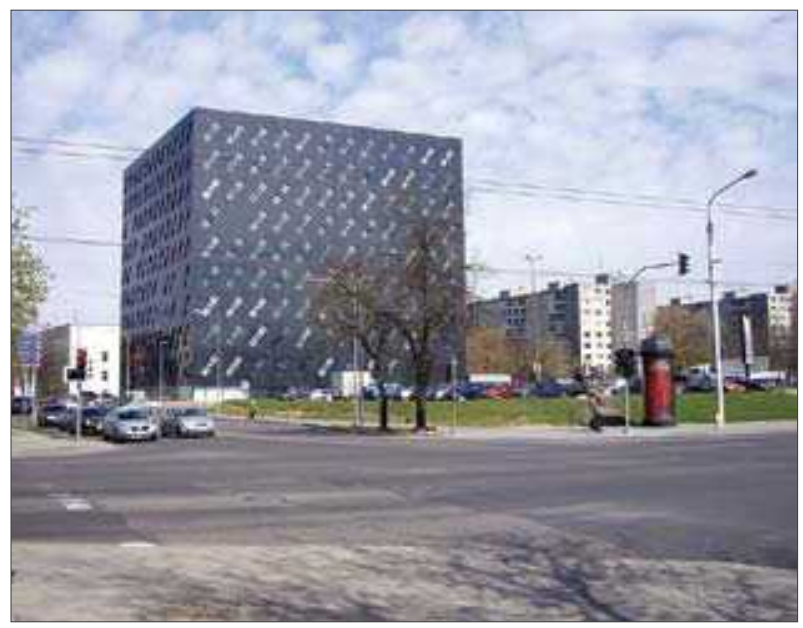

6 pav. Generalinès prokuratūros pastatas

Fig. 6. General Public Prosecutor's Office Building

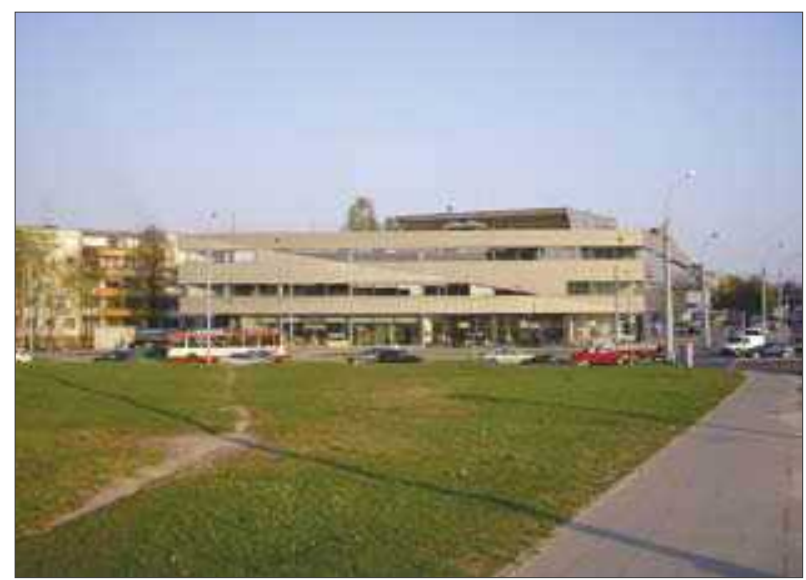

8 pav. Administracinis pastatas Žirmūnu g.

Fig. 8. Administration building in Žirmūnai str

paryškintas intensyvia spalva, tampa itin agresyvus, slopinantis aplinkinį užstatymą. Panašų efektą kelia ir Generalinès prokuratūros pastatas. Masyvios formos tūris, sustiprintas aplinkiniame užstatyme nenaudojamu tamsiu tonu, yra itin kontrastingas, deklaratyvus. Dažniausiai tai sukelia prieštaringą žiūrovų reakciją.

3 schema - paviršius ir spalva. Pavyzdžiai: daugiabučiai gyvenamieji namai Lazdynų mikrorajone (9 pav.), daugiabutis Šeškinès mikrorajone (UAB „Vilniaus architektūros studija“, 10 pav.), Viršuliškių skg. (UAB "Architektūros linija“, 11 pav.) ir Perkūnkiemyje (UAB „AKG“, 12 pav.).

4 schema - paviršius ir šviesa. Pavyzdžiai: administraciniai pastatai Mènulio g., Vilniuje (UAB „Trys A. M.“ ir UAB „AKG“, 13 pav. ), administraciniai 


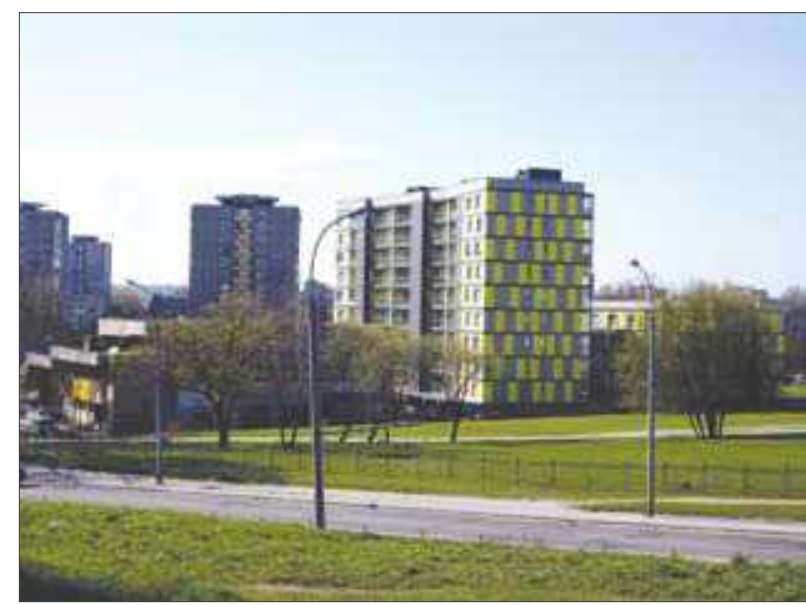

9 pav. Daugiabučiai gyvenamieji namai Lazdynų mikrorajone

Fig. 9. Apartment blocks in Lazdynai district

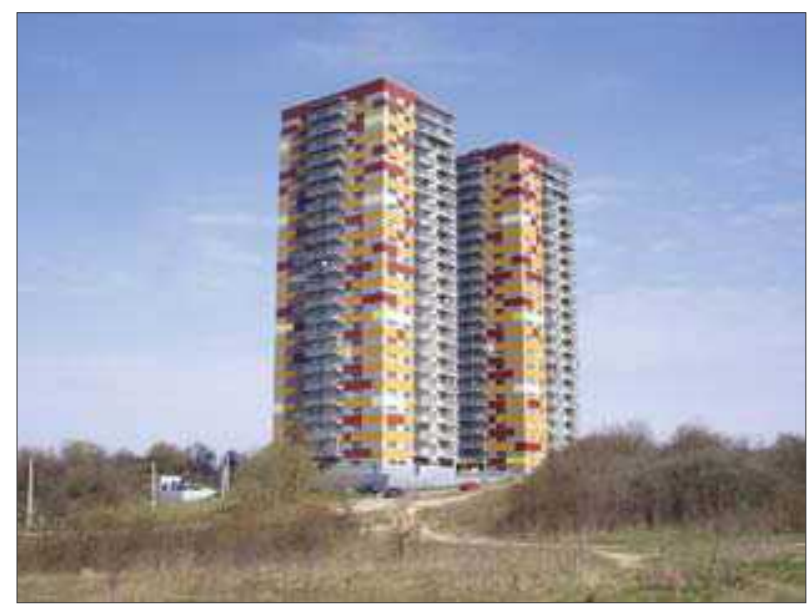

11 pav. Daugiabučiai gyvenamieji namai Viršuliškių skg.

Fig. 11. Apartment blocks in Viršuliškès crossroad

pastatai Goštauto g. („Paleko ARCH studija“ ir UAB „S. Pamerneckio kūrybinè grupë“, 14 pav.).

Nors nagrinėjimo pradžioje nebuvau užsibrèžęs nagrinèti pastatų kitais nei spalviniais aspektais, reikia pažymèti, kad šiuose pavyzdžiuose ryškus tipologinis skirstymas. Administraciniuose pastatuose naudojama achromatinè schema, gyvenamieji pastatai spalvinami. Remiantis tokiu spalviniu kodu galima gana lengvai spręsti apie stambesnių pastatų kompleksų paskirti. Goštauto g. esantis „Verslo trikampis“ gana lengvai atpažistamas kaip administracinis kvartalas. Perkūnkiemio kvartale remiantis spalviniu kodu lengvai atskiriama administracinè ir gyvenamoji kvartalo dalys. Kituose kvartaluose, pvz., Konstitucijos aikštę

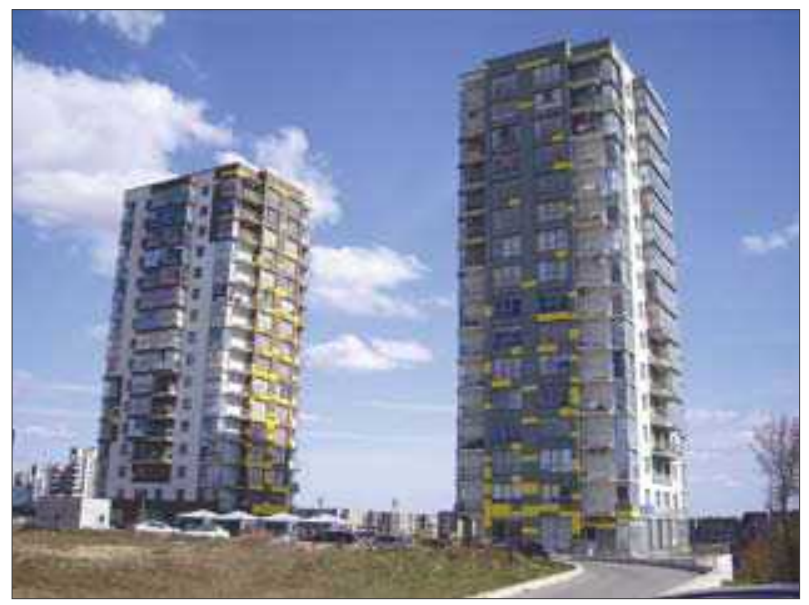

10 pav. Daugiabutis gyvenamasis namas Šeškinès mikrorajone

Fig. 10. Apartment block in Šeškinè district

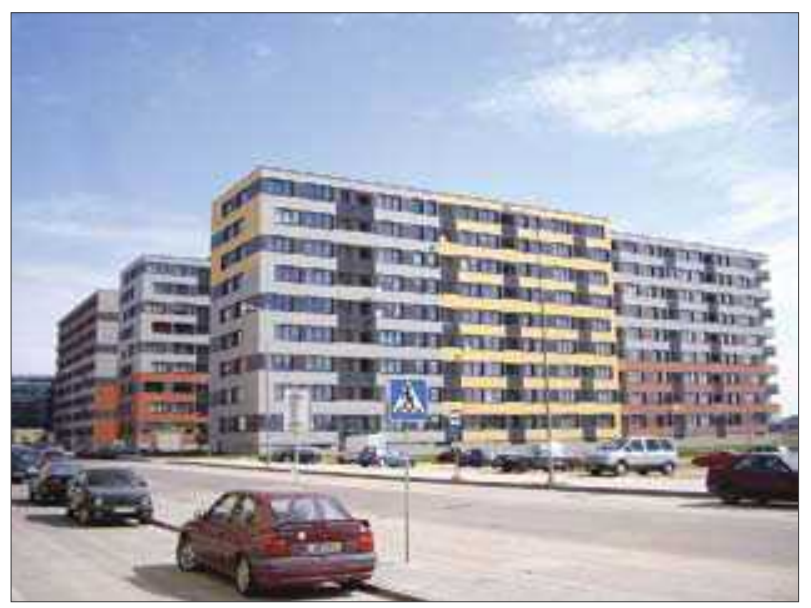

12 pav. Daugiabutis gyvenamasis namas Perkūnkiemio mikrorajone

Fig. 12. Apartment block in Perkūnkiemis district

supančiame komplekse, gana marga spalvinè kompozicija sufleruoja, kad tai polifunkcinis kvartalas.

Pastatuose naudojami spalviniai deriniai labai įvairūs. Nuo šalto tono derinių Lazdynų bei Šeškinès mikrorajonuose iki šilto Justiniškių ir Fabijoniškių mikrorajonuose esančiuose pastatuose. Spalvinio spektro pasirinkimas kiek siauresnis. Labai reta pastatų, kuriuose panaudota mèlyna arba jai artimos spalvos, ir nedaug pastatų, kuriuose naudojama žalia spalva. Nagrinètuose pavyzdžiuose dažniausiai matomas koloritas: geltonos, oranžinès, rudos spalvų deriniai.

Spalvos naudojimo pateiktuose pavyzdžiuose skalè itin plati - nuo atskirų akcentų, detalių ir lengvų spalvinių tonų iki didesnès procentinès pastato dalies 


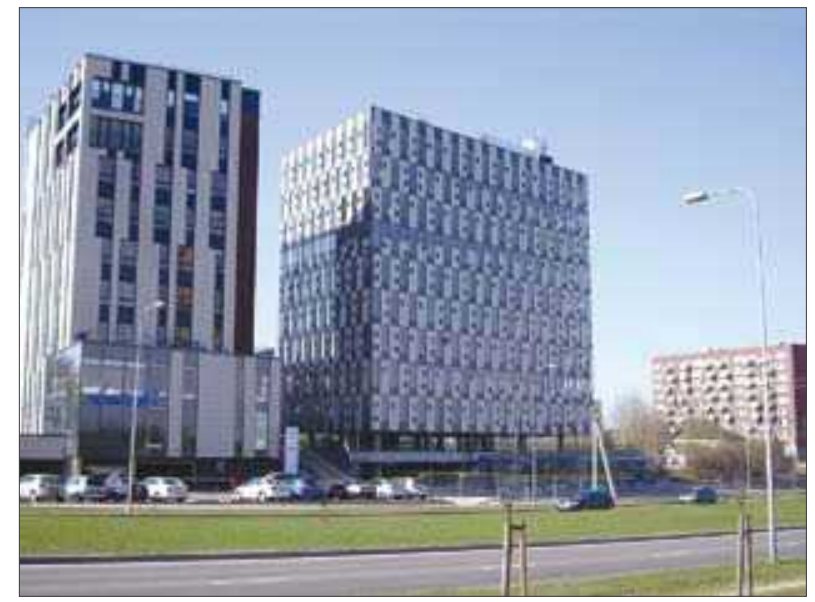

13 pav. Administraciniai pastatai Ménulio g.

Fig. 13. Administration buildings in Menulis str

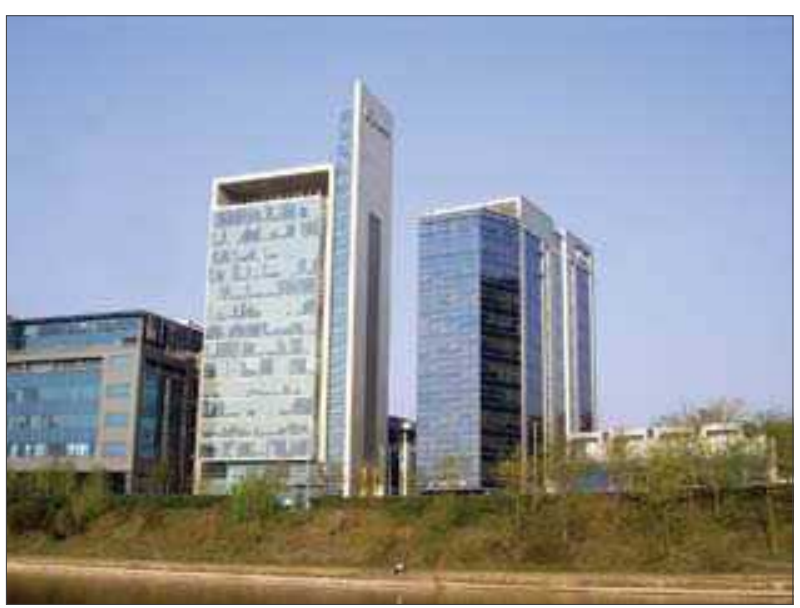

14 pav. Administraciniai pastatai Goštauto g.

Fig. 14. Administration buildings in Goštautas str

spalvinimo ir intensyvių derinių naudojimo. Spalvos santykis su urbanistine aplinka šiuose pavyzdžiuose taip pat nevienareikšmis. Lazdynų mikrorajono naujieji pastatai išsiskiria nebūdingu fasadų skaidymu ir sintetine, kontekstui taip pat nebūdinga spalva. Mano galva, tai blogas sprendimas. Intensyvūs, aukščiu išsiskiriantys pastatai Viršuliškèse gali tapti besiformuojančio aplinkinio rajono kompozicine dominante ir aiškiu spalviniu orientyru.

Gyvenamuose pastatuose išryškejjo ir dar viena tendencija. Atsirado galimybè naudoti labai platų spalvų spektrą, kitokias fasadų apdailos technologijas. Dekoruojamas fasado paviršius nebeiliustruoja tektoninès pastato schemos, jo aukštingumo, dydžio. Spalva, paviršiaus faktūra ar tekstūra nebepabrēžia atskirų fasado elementų. Dažnai elgiamasi atvirkščiai, skirtingiems elementams suteikiama ta pati spalva, o fasadai maskuoja, ardo tūrị. Nauji pastatai palaipsniui tampa efemeriški, lyginant su tarybinio laikotarpio stambiaplokštess statybos daugiaaukščiais. Naujiems daugiaaukščiams pastatams kuriamas ne „atskirai stovinčio monumento“, „skulptūros“, o „reginio“ ivvaizdis.

Baigiant glaustą spalvų naudojimo Vilniaus mieste apžvalgą, reikètų paminèti dar du spalvos naudojimo būdus, nepriskiriamus prie minètų schemų. Pirmasis būdas yra glaudžiai susijęs su naujų apdailos medžiagu gamybos technologijomis, jau patekusiomis i Lietuvą ir panaudotomis skirtinguose miestuose ir objektuose. Tai - apdailos plokščių gamybos būdas, kai paviršiaus spalva priklauso nuo krintančios šviesos kampo. Ši apdailos ypatybè kelia paradoksalius potyrius, nes pastatas, padengtas viena spalva, atrodo dvispalvis arba keičia jas priklausomai nuo žiūrèjimo kampo. Tokiu pavyzdžiu gali būti administracinis pastatas Vilniaus prieigose, automagistralèje $\mathrm{A} 2$ (UAB „AKG“, 15 pav.).

Antrasis netipinis spalvos naudojimo būdas yra dirbtinis pastatų apšvietimas naktį. Ir nors šiuo atveju reikètų kalbèti apie šviesą, iš tiesų čia taip pat neišvengiama spalvinès problematikos, o apšvietimo sprendimuose nuolat minimos ir naudojamos spalvinès (šiltas tonas, šaltas tonas ir pan.) kategorijos. Manau, kad naktinis miesto vaizdas gali produktyviai papildyti spalvinę architektūros problematiką (Valevičius 2008).

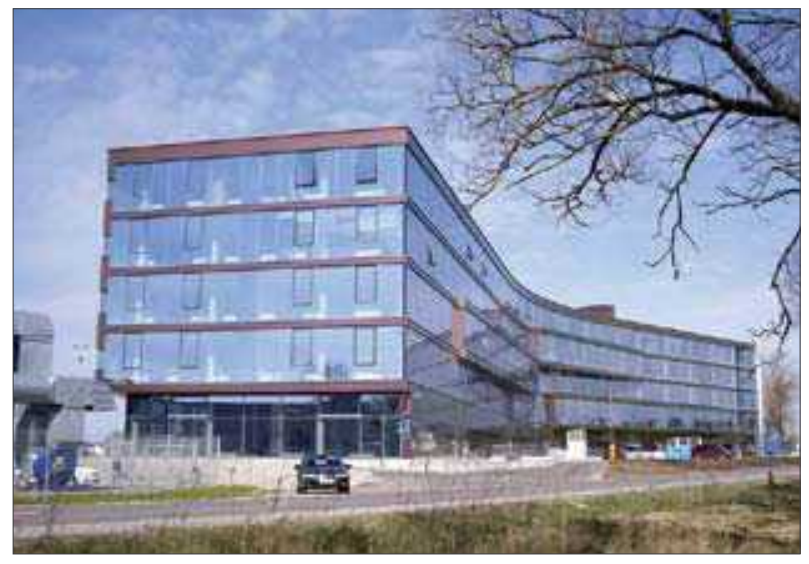

15 pav. Administracinis pastatas Vilniaus prieigose, automagistraleje $A 2$

Fig. 15. Administration building on Vilnius access highway $\mathrm{A} 2$ 
Apšvietimas labai įdomus ir kompoziciniu požiūriu, sprendžiant tūrines erdvines problemas. Ypač stikliniuose pastatuose, kai dieną buvęs vientisas luitas nakti visiškai pasikeičia, išryškèjus vidinei struktūrai (administraciniai pastatai Goštauto g. UAB „S. Pamerneckio kūrybinè grupé“, 16 pav.).

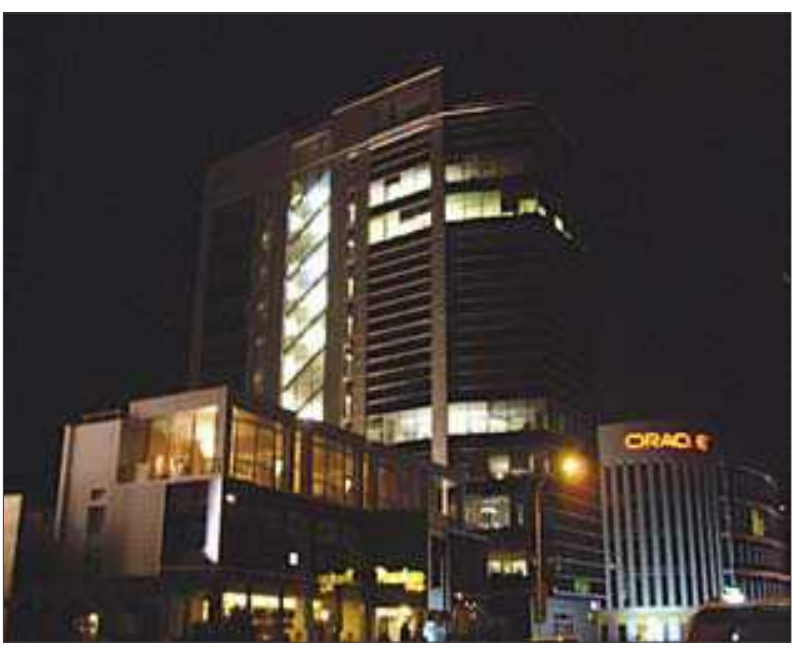

16 pav. Administraciniai pastatai nakti Goštauto $\mathrm{g}$.

Fig. 16. Administration buildings at night in Goštautas str

\section{Išvados ir apibendrinimai}

1. Nagrinejjant stambaus mastelio spalvines kompozicijas, pastebèta, kad mieste neveikia holistiniu, visuotiniu principu funkcionuojantys spalviniai savitumai. Naujoji architektūra nesiekia miestui ar mikrorajonui būdingų spalvinių sprendimų.

2. Mieste vienu metu yra taikomos skirtingos spalvinès idèjos. Viena iš jų tęsia modernistinę achromatinès architektūros kryptị, kita - bando pratęsti spalvos naudojimo tradicijas architektūroje. Todèl tokiam pačiam uždaviniui spręsti gali būti panaudoti visiškai priešingi sprendimo būdai ir gautas visiškai kitoks rezultatas.

3. Nagrinėjant atskirų pastatų spalvines kompozicijas, pastebimas siekis atskirti spalvą nuo kompozicijos tektonikos. Pastatai kuriami kaip vizualiai netektoniški objektai. Vietoj tūrio kuriamas reginys.

4. Žvelgiant ị bendrą praejjusio dešimtmečio panoramą, derètų konstatuoti, kad kyla spalvos naudojimo kultūra ir kokybè, o platesniame kultūriniame, technologiniame, geografiniame architektūros kontekste vis sunkiau įžvelgiamos ribos tarp iki šiol buvusių idejjų, vietovių ir sprendimų.

\section{Literatūra}

Jonaitis, A. 2008. Spalvotyra. Kaunas: Terra Publica.

Mogilnickas, I. 1995. Technines estetikos pradmenys. Vilnius.

Samalavičius, A. 2004. Idejos ir struktūros architektūros istorijoje. Vilnius: Kultūros barai.

Valevičius, M. 2008. Naktinis miestovaizdis: samprata, tipologija ir planavimas,_Urbanistika ir architektūra 32(1): 48-57. doi: 10.3846/1392-1630.2008.32.48-57

Warncke, C. 1990. De Stijl 1917-1931. Koln: Taschen.

Араухо, И. 1982. Архитектурная композиция. Москва: Высшая школа.

Иттен, И. 2004. Основы иввета. Москва: Д. Аронов.

\section{COLOUR IN THE NEW ARCHITECTURE OF VILNIUS}

\section{R. Kučinskas}

Abstract. This paper attempts to make a review of reasons for the use of colour, bringing together the guidelines for the analysis of colour in architectural composition and analysing the use of colour in the new Vilnius architecture during the first years of the 21 st century.

The overview of colour usage in Vilnius architecture was based on the methodical scheme proposed by I. Araujo. As far as the relation between colour and architecture is concerned, he suggests employment of the following closely intertwined components: volume and surface, colour and light. Light in the Araujo's scheme is not solely a physical or metaphysical factor; it is an equivalent compositional constituent part in terms of colour. The foregoing allows including the stages of achromatic modern architecture into the research of chromatic composition.

Having carried out an overview of colour usage in today's architecture of Vilnius, it must be stated that the peculiarities functioning in the city are not based on holistic or global principles. Different chromatic conceptions are simultaneously applied in the city. One of them pursues a contemporary achromatic line in architecture. The other conception makes an attempt at continuing the tradition of colour usage in architecture.

Keywords: volume, surface, colour, light, composition, chromatic conception.

\section{ROMUALDAS KUČINSKAS}

Assoc Prof, Dept of Architecture, Vilnius Academy of Fine Arts, Maironio g. 6, LT-01124 Vilnius, Lithuania.

E-mail:rkucinskas@yahoo.com

Teaching: architectural composition, architectural design, history of modern architecture, critical analysis of architecture. Publications: author of 6 scientific publications, 70 publications in professional press and author of 1 monograph. Projects: author or co-author of 26 realizations of projects of architectural design. Research interests: theory and history of architectural composition. 